\title{
HEAVY METAL SOIL CONTENT AS AN INDICATOR OF POLLUTION
}

\author{
ANA-MARIA RUSU ${ }^{1}$, WILLIAM DUBBIN ${ }^{2}$, NICOLAE HAR ${ }^{3}$, \\ KATALIN BARTOK ${ }^{4}$, WILLIAM PURVIS ${ }^{5}$, BEN WILLIAMSON ${ }^{2}$
}

\begin{abstract}
Two soil sample series were collected from 7 contaminated sites situated along a transect from the pollutant source, Zlatna copper ore-processing plant, and analyzed using different analytical methods. The soils collected in 1998 were analyzed by inductively coupled plasma-atomic emission spectrometry (ICP-AES) after extraction with DTPA for trace metals and those collected in 1999 were analyzed with flame atomic absorption spectrometry (FAAS) following two acid digestion procedures. The DTPA extraction procedure produced lower results than the acid digestions. Also, the $\mathrm{pH}$ values for all samples was measured and the results obtained during autumn compared with those in spring after a long winter with heavy snow falls. The correlation between $\mathrm{Cu}, \mathrm{Pb}, \mathrm{Zn}$ (for samples collected in May 1999) and $\mathrm{pH}$ was investigated. The pattern of chemical abundance of contaminants $(\mathrm{Cu}, \mathrm{Pb}, \mathrm{Zn}, \mathrm{Fe}, \mathrm{Cd}$ and $\mathrm{Ni}$ ) was determined in soil at $0-50 \mathrm{~cm}$ depth. This study indicates that $\mathrm{Pb}$ is the most polluting element up to $25 \mathrm{~km}$ downwind from Zlatna town.
\end{abstract}

\section{INTRODUCTION}

Atmospheric deposits and the disposal of a variety of wastes on land have recently been found to increase a range of biologically important metals in soils, sometimes to harmful levels [1]. Soil acts as a buffer by controlling the bioavailability and transport of toxic substances in the environment. Many contaminants are thus immobilised by soil, and the risk to ecosystem health is therefore reduced. The concentration of heavy metals is associated with biological and geological cycles [2].

The main environmental damages in the area of Zlatna (Romania) town are caused by mining and mineral processing. Metal contamination from minerals processing of Zlatna town has lead to environmental degradation over a wide area around smelter emissions. Gaseous emissions $\left(\mathrm{SO}_{2}, \mathrm{NOx}\right)$ and fall-out of particles enriched in $\mathrm{Pb}, \mathrm{Zn}, \mathrm{Cu}$ and $\mathrm{Cd}$ from the

\footnotetext{
${ }^{1}$ Department of Chemistry, Babes-Bolyai University, Cluj-Napoca, Romania

${ }^{2}$ Department of Mineralogy, The Natural History Museum, London, UK

${ }^{3}$ Department of Geology, Babes-Bolyai University, Cluj-Napoca, Romania

${ }^{4}$ Department of Biology, Babes-Bolyai University, Cluj-Napoca, Romania

${ }^{5}$ Department of Botany, The Natural History Museum, London, UK
} 
Ampelum S.A. processing plant and smelter cause acid precipitation and heavy metal contamination. These effects have their greatest intensity in the proximity of the plant, but they are also important along the Ampoi Valley until Alba lulia town ( $30 \mathrm{~km}$ down wind of Zlatna). The extent to which the area has been affected by pollution depends on local weather conditions and changes in wind direction. The soils from the study area accumulated varying amounts of trace metals (e.g. $\mathrm{Cu}, \mathrm{Pb}, \mathrm{Zn}, \mathrm{Cd}, \mathrm{Sb}$, and $\mathrm{Bi})$. Trace metal concentrations are highest in soils near the smelter. The concentration of the metals in soil is controlled by the $\mathrm{pH}$ of the environment and the low $\mathrm{pH}$ values $(3.20-4.42)$ of the sampled soils are the result of the acidic rain. The degree of soil contamination depends on the type of the present metals, their concentration and their bioavailability. The bioavailability of different metals is dependent on soil $\mathrm{pH}$, the type of organisms present, as well as a wide range of other environmental variables.

Local streams and the Ampoi River receive contaminated water in the form of acid, and occasionally highly alkaline, smelter effluent and metal enriched acid leachates from the approximately $1 \mathrm{~km}^{2}$ tailing heaps around the processing plant. In some areas these drain directly onto local agricultural land. The acid nature of the leachates is due to the oxidation of sulphide minerals, particularly pyrite $\left(\mathrm{FeS}_{2}\right)$ and galena $(\mathrm{PbS})$, which remain in the tailings due to inefficient extraction in the processing plant. Sulfur is released in the form of sulfate $\left(\mathrm{SO}_{4}{ }^{2-}\right)$ which dissolves to produce weak sulfuric acid in which potentially toxic elements are solubilised.

Previous studies on soil contamination from Zlatna area focused on the assessment of $\mathrm{Pb}$ and $\mathrm{Cd}$ in agricultural soils [3]. Gurzau et al. [4] studied the accumulation of $\mathrm{Pb}$ in the blood of local children as a result of the polluted environment. Williamson et al. [5] evaluated the environmental damage from the Zlatna area and Rusu et al. [6] studied the multielemental monitoring of soil correlated with its $\mathrm{pH}$, in Zlatna region.

In this study two series of soil samples were collected from 7 contaminated sites situated along a transect from $0.3-25 \mathrm{~km}$ from the pollutant source. These soils were subsequently analyzed with different analytical methods. The sampling sites have been described in detail elsewhere [6]. The soils collected in 1998 were analyzed by ICP-AES after extraction with DTPA for trace metals and those collected in 1999 were analyzed with FAAS following two acid digestion procedures. The $\mathrm{pH}$ values were measured in all samples to assess the influence of a long, snowy winter on the $\mathrm{pH}$ values. Possible correlations between $\mathrm{Cu}, \mathrm{Pb}, \mathrm{Zn}$ (the dominant contaminant elements) and $\mathrm{pH}$ were studied. The pattern of chemical abundance of contaminants $(\mathrm{Cu}, \mathrm{Pb}, \mathrm{Zn}, \mathrm{Fe}, \mathrm{Cd}$ and $\mathrm{Ni})$ was determined in soil at $0-50 \mathrm{~cm}$ depth. 


\section{EXPERIMENTAL METHODS}

Three different dissolution procedures were used to determine the metal contents of the soils : (I) extraction with DTPA, (II) acid digestion with $\mathrm{HNO}_{3}+\mathrm{HCl}(3: 1 \mathrm{v} / \mathrm{v})$ (i.e the Lunge method) and (III) digestion with $\mathrm{HNO}_{3}+$ $\mathrm{H}_{2} \mathrm{O}_{2}$.

\section{Method I}

$20 \mathrm{ml}$ of the DTPA and TEA extraction solutions were added to $10 \mathrm{~g}$ of air-dried soil in a $125 \mathrm{ml}$ conical flask. Each flask was covered with stretchable parafilm and secured upright on a horizontal shaker. After exactly 2 hours of shaking, the suspensions were filtered by gravity through Whatman no. 42 filter paper. The filtrate may be analysed for the trace metals $\mathrm{Cu}, \mathrm{Ni}$, $\mathrm{Zn}, \mathrm{Pb}, \mathrm{Fe}$ and $\mathrm{Cd}$ by ICP- AES.

\section{Method II}

$10 \mathrm{ml}$ of $1: 1(\mathrm{v} / \mathrm{v}) \mathrm{HCl}$ was added to $0.2 \mathrm{~g}$ of air-dried soil in a $150 \mathrm{ml}$ beaker and the sample heated to near dryness. After cooling, $10 \mathrm{ml}$ of $3: 1(\mathrm{v} / \mathrm{v})$ $\mathrm{HNO}_{3}+\mathrm{HCl}$ Lunge mixture, was added, and again the acid was evaporated to near dryness. The residue was dissolved in $25 \mathrm{ml} \mathrm{HCl} 1: 4(\mathrm{v} / \mathrm{v})$ and heated for approximately 15 minutes in open air. The sample was then transferred into a $100 \mathrm{ml}$ volumetric flask and diluted to volume with distilled water. The sample was filtered to remove suspended particulate matter before analysis.

\section{Method III}

$14 \mathrm{ml} \mathrm{HNO}{ }_{3} 65 \%(\mathrm{~m} / \mathrm{v})$ was added to $0.2 \mathrm{~g}$ of air-dried soil in a $150 \mathrm{ml}$ beaker. This dissolution was carried out over night at room temperature, then heated for 1 hour at $50^{\circ} \mathrm{C}$, then 3 hours at $120^{\circ} \mathrm{C}$. After cooling, $6 \mathrm{ml}$ $\mathrm{H}_{2} \mathrm{O}_{2} 30 \%(\mathrm{~m} / \mathrm{v})$ was added and reheated to $120^{\circ} \mathrm{C}$ until brown fumes were no longer visible. The resulting sample was cooled and brought to $100 \mathrm{ml}$. Suspended particulate matter was removed by filtration.

\section{Instrumentation}

An ARL3410 "Minitorch" Sequntial ICP-AES was used for trace element determination in soil samples collected in 1998 and processed with method I. All measurements were background corrected; all reagents were analytical grade or better. The instrument response was calibrated using synthetic multielement standards prepared from certified single element solution.

Samples collected in 1999, digested with methods II and III, were analysed using a Perkin Elmer 3030E instrument. The measurements were made using an air-acetylene flame, without noise compensation and with a slit of $0.7 \mathrm{~nm}$. Zinc was measured at the resonance line of $213.9 \mathrm{~nm}$, copper at $324.8 \mathrm{~nm}$ and lead at $217 \mathrm{~nm}$. The spectrometer was calibrated using standard solutions. 


\section{Determination of contaminant elements in soils.}

The comparative results obtained with soil samples analysed using two acid dissolution procedures are presented (Figure 1).

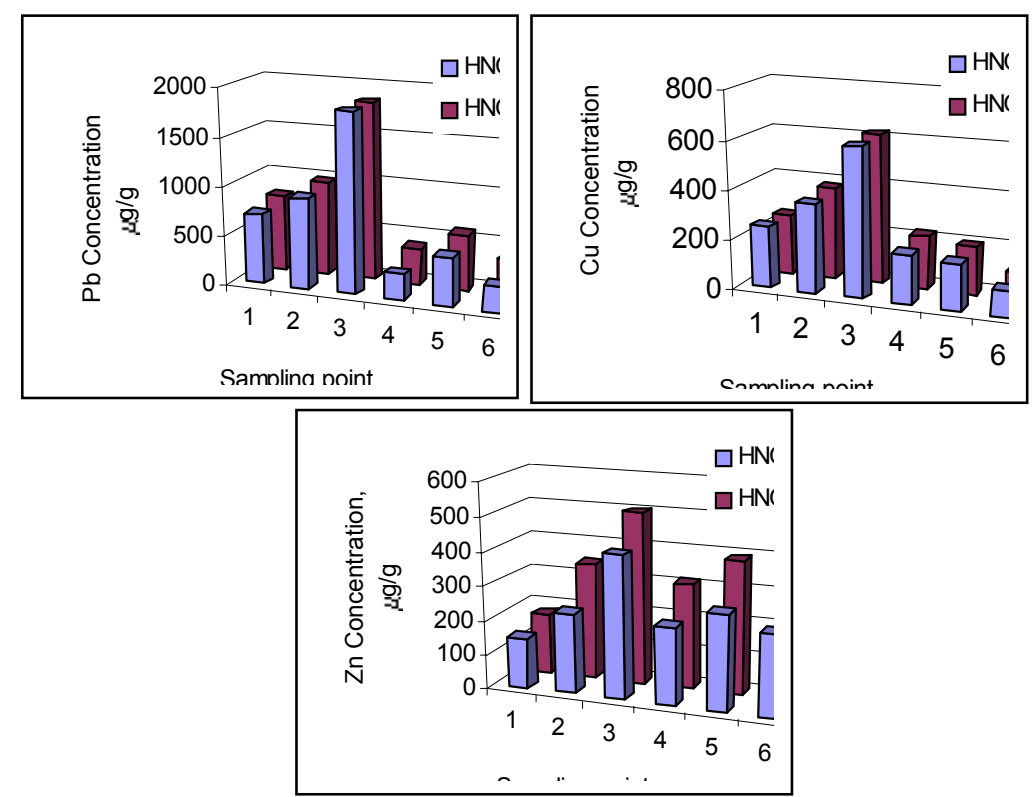

Fig. 1. Comparison between the Lunge and acid-peroxide dissolution procedures

Dissolution using the Lunge methodology produces higher measured concentrations than that using acid-peroxide. This increased power of digestion may be ascribed to an increased oxidative force of the Lunge mixture.

\section{RESULTS AND DISCUSSION}

The $\mathrm{pH}$ values along the Ampoi valley determined for soils collected on October 1998 (dry autumn) and soils collected on May 1999 (wet spring, after snow melting) are shown in fig. 2. Sampling points: $1,2,3,4,5,6,7$ represent the distance from the pollutant source in $\mathrm{km}: 0.3 ; 0.5 ; 3.5 ; 4 ; 9$; 16; and 25, respectively. Sites 1 and 2 are localized in Zlatna town, 3 and 4 in Patrangeni, 5 Presaca Ampoi, 6 Metes and 7 Ampoita. 


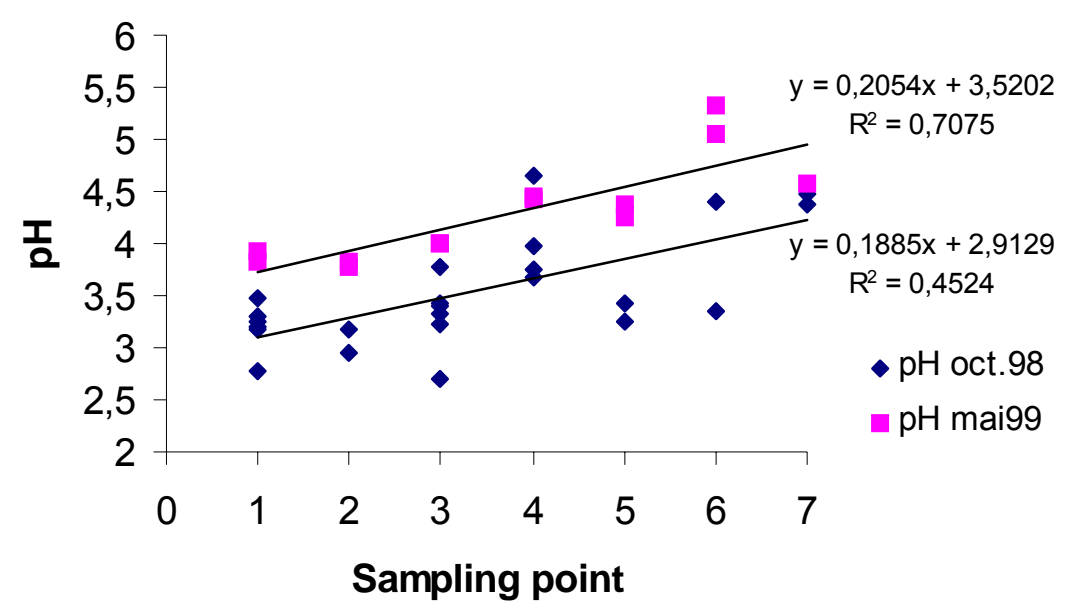

Fig. $2 \mathrm{pH}$ values of soils collected along a transect in Zlatna area.

The $\mathrm{pH}$ values of soils in the studied area range between 2.7 to 4.7 for soils collected in autumn 1998, and between 3.8 to 5.3 for soils collected in spring 1999. These $\mathrm{pH}$ values are sufficiently low to considerably increase the bioavailability of metals. The spring $\mathrm{pH}$ values are greater than autumn $\mathrm{pH}$ values, this is normal and to be expected because the snow water dilutes the soil acidity. Also, it is interesting to observe the correlation coefficient values of soils $\mathrm{pH}$ versus distance from the pollutant source for spring $(0.7075)$ and for autumn (0.4524). Maybe the humidity has unified the acidity of soil. In an area such as Zlatna, where $\mathrm{SO}_{2}$ deposition is high, the $\mathrm{pH}$ values increase slowly with increasing distance from pollutant source. However, all soils within $25 \mathrm{~km}$ of the smelter were acidic.

Correlations between element concentrations and soil $\mathrm{pH}$ (for samples collected in May 1999) are shown (Figure 3).

For copper and lead it would appear that the concentration of metals in soil is dependent on $\mathrm{pH}$. In more acid environments these metals are present at higher concentrations. It may be postulated that this relationship is the result of chemical complexes being formed in the soil - or a specific part of the soil e.g. humus - only at certain pH ranges. There is no reason, from this data, to believe that the accumulation of zinc is related to acid $\mathrm{pH}$.

Comparison between $\mathrm{Pb}, \mathrm{Cu}$ and $\mathrm{Zn}$ concentration determined October 1998 (DTPA) and May 1999 (Lunge) are shown (Figure 4). In all cases the metal concentrations after acid digestion are higher than following DTPA extraction (acid mixture extracts total metal and DTPA only bioavailable metal). Also, heavy metals are most mobile, and bioavailable, under acid conditions, thus $\mathrm{Pb}$ and $\mathrm{Cu}$ concentrations for both procedures exceed the 
maximum acceptable concentration ( $\mathrm{Pb}-20 \mathrm{mg} / \mathrm{kg}, \mathrm{Cu}-20 \mathrm{mg} / \mathrm{kg}$ ) [7]. The most polluted site is Patrangeni station (site 3), despite being $3.5 \mathrm{~km}$ from the smelter chimneys. This is probably due to meteorological conditions in which smelter plumes are being blown towards the north east as well as a looping plume coming to the ground as a consequence of thermal convection currents. Generally, the $\mathrm{Pb}$ and $\mathrm{Cu}$ concentrations tend to decrease with distance from the pollutant source.
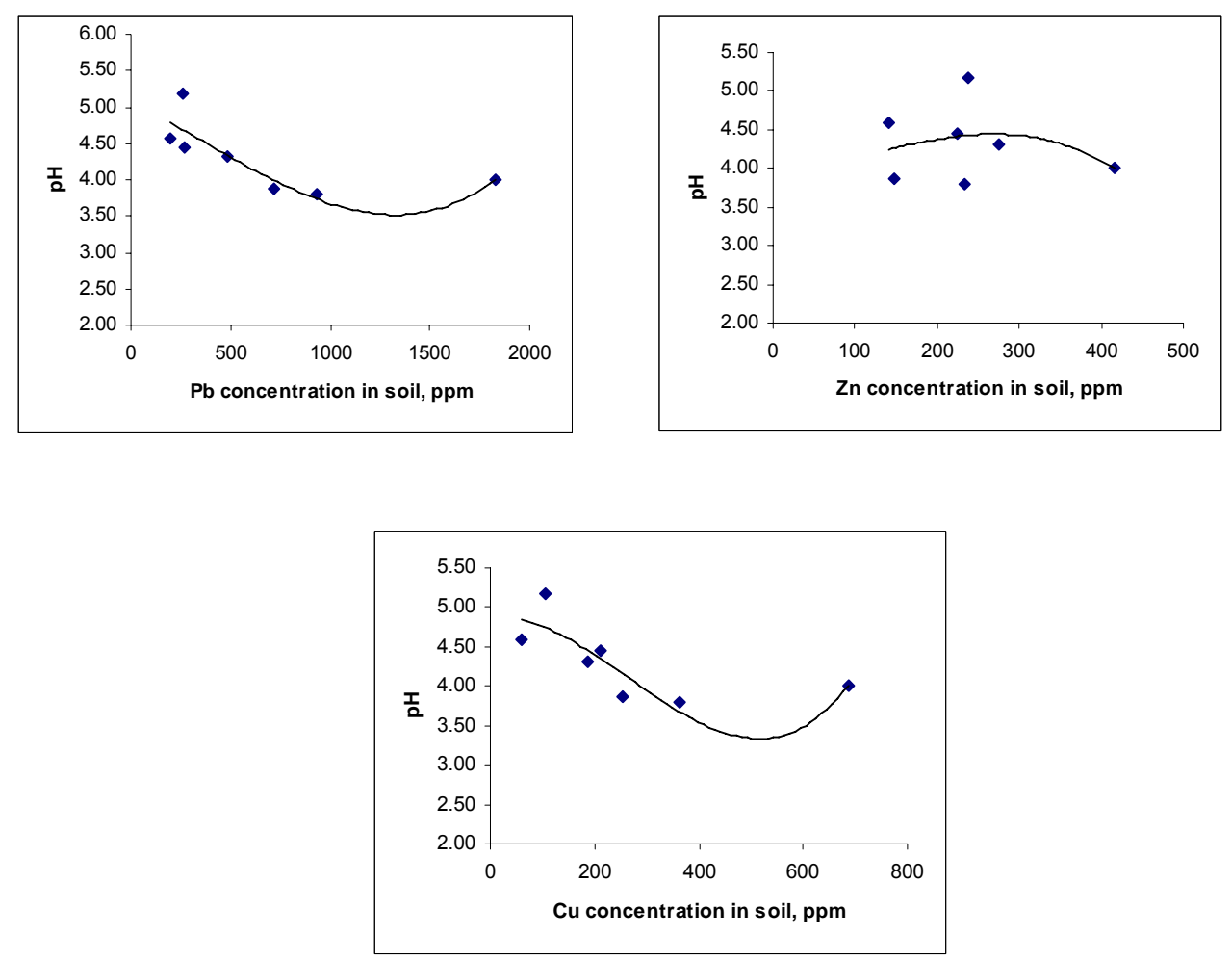

Fig. $3 \mathrm{~Pb}, \mathrm{Zn}$ and Cu concentration versus soil $\mathrm{pH}$

Variation of metal concentration in soil layers was studied in site 3 Patrangeni, the most polluted site investigated in Zlatna region. Also at site 1 (Zlatna town), the metal concentration was determined at $50 \mathrm{~cm}$ depth (Table 1). 
HEAVY METAL SOIL CONTENT AS AN INDICATOR OF POLLUTION

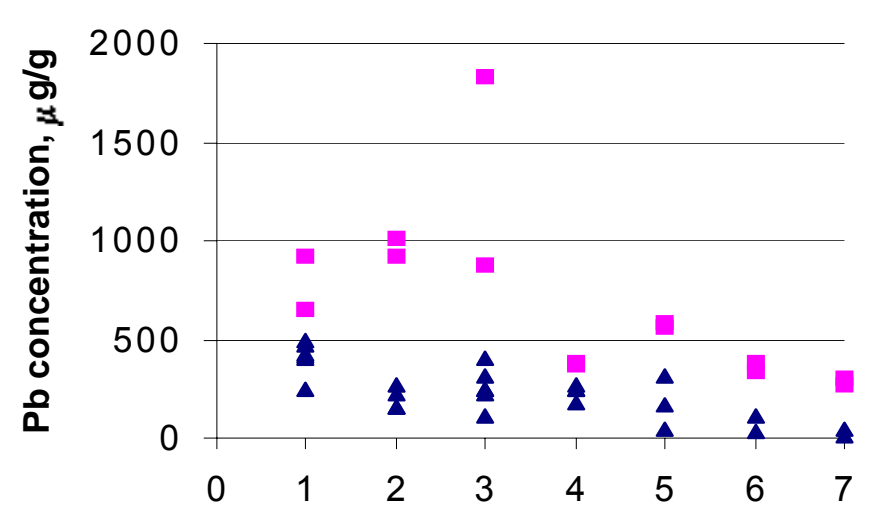

$\triangle \mathrm{Pb}(\mathrm{DTPA})$

$\mathrm{Pb}$ (Lunge)

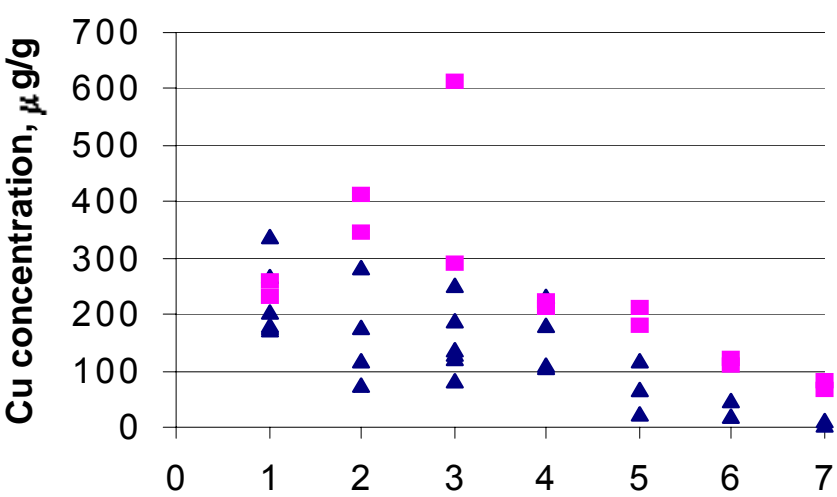

$\triangle \mathrm{Cu}(\mathrm{DTPA})$

- Cu (Lunge)

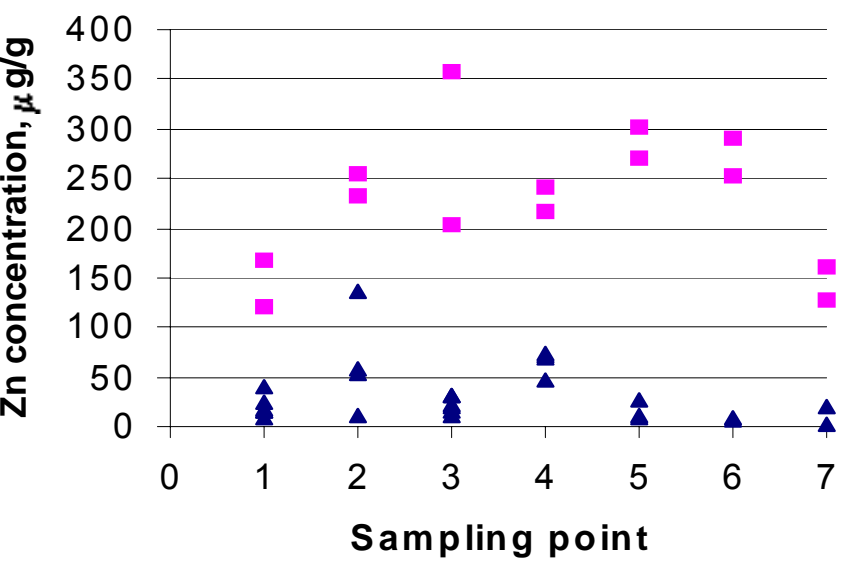

$\triangle$ Zn (DTPA)

- Zn (Lunge)

Fig. 4 Comparison between $\mathrm{Pb}, \mathrm{Cu}$ and $\mathrm{Zn}$ contents in soils collected on autumn 1998 (DTPA) and spring 1999 (Lunge). 
Table 1.

Metal concentration $(\mu \mathrm{g} / \mathrm{g})$ at various soil depths.

\begin{tabular}{|c|c|c|c|c|c|c|}
\hline \multirow[b]{2}{*}{ Site } & \multirow[b]{2}{*}{ Element } & \multicolumn{2}{|c|}{ Surface } & \multirow[b]{2}{*}{$5 \mathrm{~cm}$} & \multirow[b]{2}{*}{$10 \mathrm{~cm}$} & \multirow[b]{2}{*}{$15 \mathrm{~cm}$} \\
\hline & & $\begin{array}{l}\text { Organic } \\
\text { layer } 1\end{array}$ & $\begin{array}{l}\text { Organic } \\
\text { layer } 2\end{array}$ & & & \\
\hline \multirow[t]{2}{*}{ Profile 1} & $\mathrm{~Pb}$ & 127.9 & & 9.6 & 6.3 & 3.4 \\
\hline & $\mathrm{Cu}$ & 118.8 & & 20.5 & 10.8 & 6.6 \\
\hline \multirow{4}{*}{$\begin{array}{l}\text { Patrangeni } \\
\text { Forest }\end{array}$} & $\mathrm{Zn}$ & 14.1 & & 6.4 & 5.6 & 10.8 \\
\hline & $\mathrm{Cd}$ & 0.13 & & 0.10 & 0.12 & 0.15 \\
\hline & $\mathrm{Fe}$ & 513.9 & & 96.7 & 68.3 & 66.8 \\
\hline & $\mathrm{Ni}$ & 0.12 & & 0.04 & 0.09 & 0.06 \\
\hline \multirow[t]{2}{*}{\begin{tabular}{|l} 
Profile 2 \\
\end{tabular}} & $\mathrm{~Pb}$ & & 546.2 & 246.2 & & 1.4 \\
\hline & \multirow{5}{*}{$\begin{array}{l}\mathrm{Cu} \\
\mathrm{Zn} \\
\mathrm{Cd} \\
\mathrm{Fe} \\
\mathrm{Ni}\end{array}$} & & 152.9 & 53.6 & & 2.3 \\
\hline \multirow{4}{*}{\begin{tabular}{|l|} 
Patrangeni \\
Open land \\
\end{tabular}} & & & 9.0 & 9.2 & & 6.3 \\
\hline & & & 0.08 & 0.13 & & 0.11 \\
\hline & & & 521.4 & 390.8 & & 15.0 \\
\hline & & & 0.07 & 0.11 & & 0.09 \\
\hline Site 1 Zlatna & $\mathrm{Pb}$ & $\mathrm{Cu}$ & $\mathrm{Zn}$ & $\mathrm{Cd}$ & $\mathrm{Fe}$ & $\mathrm{Ni}$ \\
\hline $50 \mathrm{~cm}$ depth & 16.5 & 12.0 & 41.7 & 0.71 & 51.1 & 0.33 \\
\hline
\end{tabular}

Profile 1 was located within the protected environment of a forest, and Profile 2 was located in open land, highly exposed to the pollution. The results presented in Table 1 emphasise the importance of the microhabitat on the extent of soil contamination. For $\mathrm{Pb}, \mathrm{Cu}$ and $\mathrm{Fe}$ the highest metal concentrations were observed in the organic layer, and these concentrations decreased with depth. Variation of $\mathrm{Zn}, \mathrm{Cd}$ and $\mathrm{Ni}$ concentrations are insignificant up to $15 \mathrm{~cm}$ depth. Levels of metals found in soil in Zlatna town (site1) at $50 \mathrm{~cm}$ depth are higher than that at Patrangeni (site3, $3.5 \mathrm{~km}$ from pollutant source) at $15 \mathrm{~cm}$ depth (with the exception of $\mathrm{Fe}$ ).

In soil, metal concentration gradients are apparent with depth. Extremely high metal contents were measured in the organic layer surface, followed by a marked decrease in the underlying soil horizons. The humus rich organic layers have high capacities to sorb metals and prevent or retard their movement down the soil profile.

\section{REFERENCES}

1. M.L. Berrow, J.C. Burridge, Proc. Int. Conf., London, CEP Consultants Ltd., Edinburgh, 1979, 304.

2. Y. Weimin, Z. Shen, Acta Geogr. Sin., 1987, 2, 42. 
3. M. Preda, M. Keul, G. Lazar-Keul, R. Vintila, St. Gallo, T. Piciu, Contributii Bot. (Cluj-Napoca), 1988, 269-274.

4. E.S. Gurzau, C. Ponoran, M.A. Micka, P. Billig, M. Silberschmith, Environment, Work and Health in the New Central and Eastern European Democraties, Eforie, Romania, 24-26.

5. B.J. Williamson, O.W. Purvis, K.Bartok, N. Har, E. Manolache, D. Jones, C. Stanley, N. Vlad, Studia Univ. Babes-Bolyai, Geologia, 1996, XLI, 1, 87-93.

6. AM. Rusu, K. Bartok, N. Har, B. Dubbin, W. Purvis, B. Williamson, C. Bartha, A. Vizitiu, Studii si cercetari biologie, ISBN 973-97664-7-1, Bistrita, 1999, 5, 117.

7. Monitorul Oficial al Romaniei (1997) IX, 303/l: 27. 